\title{
Perencanaan Penggunaan Lahan Berbasis Sumber Daya Air di Hulu DAS Cisadane
}

\section{(Land Use Planning Based on Water Resources in Upper Cisadane Watershed)}

\author{
Fulki Dwiyandi Araswati ${ }^{1 *}$, Kukuh Murtilaksano ${ }^{2}$, Yayat Hidayat ${ }^{2}$ \\ (Diterima Juli 2020/Disetujui April 2021)
}

\begin{abstract}
ABSTRAK
Perubahan penggunaan lahan adalah salah satu penyebab terjadinya ketidakseimbangan antara ketersediaan dan kebutuhan air. Perubahan penggunaan lahan ini sejalan dengan perkembangan wilayah dan laju pertumbuhan penduduk pada suatu daerah yang akan menyebabkan kebutuhan air terus meningkat. Daerah aliran sungai (DAS) Cisadane Hulu merupakan sumber air baku bagi masyarakat Kota dan Kabupaten Bogor, baik untuk kegiatan domestik maupun nondomestik sehingga perlu dipertahankan fungsi hidrologisnya. Tujuan penelitian ini adalah mengkaji ketersediaan dan kebutuhan air, mengkaji neraca air di DAS Cisadane Hulu, serta menyusun rekomendasi perencanaan pengelolaan lahan yang optimal. Penelitian dilaksanakan di DAS Cisadane Hulu pada tahun 2019. Analisis kebutuhan air menggunakan SNI 19-6728.1-2002 dan metode FJ Mock digunakan untuk mengetahui ketersediaan air serta penyusunan skenario perencanaan penggunaan lahan dalam memprediksi total limpasan. Terdapat enam skenario yang diterapkan yang meliputi 1) Penggunaan lahan eksisting pada tahun 2018, 2) Penggunaan lahan sesuai RTRW Provinsi Jawa Barat, 3) Rencana teknik rehabilitasi hutan dan lahan (RTk-RHL), 4) Implementasi fungsi kawasan hutan di Hulu DAS Cisadane, 5) Kombinasi antara skenario 2, 3, dan 4, dan 6) Aplikasi teknik agroforestry pada lahan pertanian/perkebunan berlereng curam. Hasil penelitian menunjukkan bahwa kebutuhan air di Daerah Tangkapan Air (DTA) Cianteun adalah sebesar 108.952.291 $\mathrm{m}^{3} /$ tahun dan di DTA Cisadane Hulu sebesar $308.733 .311 \mathrm{~m}^{3} /$ tahun, serta ketersediaan air berdasarkan debit andalan periode 10 tahun di DTA Cianteun sebesar 248.584.986 $\mathrm{m}^{3} /$ tahun dan di DTA Cisadane Hulu sebesar 301.882.316 $\mathrm{m}^{3} /$ tahun. Hasil neraca air membuktikan bahwa ketersediaan air pada DTA Cianteun mengalami surplus sebesar $139.632 .695 \mathrm{~m}^{3} / \mathrm{tahun}$, sedangkan pada DTA Cisadane Hulu mengalami defisit sebesar $-6.850 .995 \mathrm{~m}^{3} /$ tahun.
\end{abstract}

Kata kunci: kebutuhan air, ketersediaan air, limpasan total, skenario perencanaan penggunaan lahan

\section{ABSTRACT}

Land-use change is one of the causes of imbalance between water supply and demand. This land-use change is in line with the development of an area along with its population growth rate, which will cause a continuous increase of water demand. Cisadane Hulu is the main raw-water source for the citizens of Kota and Kabupaten Bogor, both for domestic and non-domestic activities. Therefore, its hydrological function needs to be maintained. The objectives of this research are to assess the water supply and demand and to assess the water balance of Cisadane Hulu watershed, also to formulate a recommendation for an optimum land-management planning. This research was conducted in 2019. Analysis with SNI 19-6728.1-2002 was applied to presume the water demand, while the Mock model was applied to determine water supply and land-use planning scenarios in predicting the total run-off. There were six scenarios implemented, i.e., 1) Implementation of Existing Land Use 2018, 2) West Java Spatial Planning, 3) RTk-RHL, 4) forest area maps, 5) Combination of scenarios 2, 3, and 4, and 6) agroforestry technique in agriculture and plantation. The results showed that the water demands in Cianteun Water Catchment Area were $108.952 .291 \mathrm{~m}^{3} / \mathrm{year}$ and in Cisadane Hulu Water Catchment Area were $308.733 .311 \mathrm{~m}^{3} /$ year, while the water supplies in Cianteun Water Catchment Area were 248.584.986 m3/year and in Cisadane Hulu Water Catchment Area were $301.882 .316 \mathrm{~m}^{3} / \mathrm{year}$. The water balance results proved that the water supply in Cianteun Water Catchment Area had a surplus of 139.632.695 m³/year, meanwhile Cisadane Hulu Water Catchment Area had a deficit of $-6.850 .995 \mathrm{~m}^{3} / \mathrm{year}$.

Keywords: land use planning scenario, total run-off, water supply, water demand

\footnotetext{
1 Sekolah Pascasarjana, Fakultas Pertanian, Institut Pertanian Bogor, Kampus IPB Darmaga, Bogor 16680

2 Pengelolaan Daerah Alliran Sungai, Fakultas Pertanian, Institut Pertanian Bogor, Kampus IPB Darmaga, Bogor 16680

* Penulis Korespondensi: Email: fulkiaraswati@gmail.com
}

\section{PENDAHULUAN}

Semua aktivitas manusia mulai dari kebutuhan domestik, pertanian, energi, pengembangan industri, dan pembangunan memerlukan ketersediaan air (Kodoatie et al. 2010). Akan tetapi, perlu disadari 
bahwa ketersediaan air di bumi semakin langka menurut ruang dan waktu baik secara kuantitas maupun kualitas. Perkembangan wilayah pada suatu daerah akan menyebabkan kebutuhan air terus meningkat seiring dengan laju pertumbuhan penduduk sehingga mengakibatkan ketidakseimbangan antara ketersediaan air yang cenderung menurun dan kebutuhan air yang semakin meningkat. Untuk mencapai keseimbangan antara kebutuhan air dan ketersediaan air di masa mendatang, diperlukan upaya pengkajian komponen-komponen kebutuhan air, serta efisiensi penggunaan air (Sari et al. 2012). DAS Cisadane Hulu merupakan kawasan yang berfungsi sebagai daerah pelindung dan penyangga wilayah keseluruhan DAS Cisadane. DAS Cisadane Hulu hingga saat ini telah mengalami banyak alih fungsi lahan. Alih fungsi lahan menyebabkan terjadi perubahan fungsi hidrologis DAS, seperti sering terjadi banjir pada musim penghujan dan kekeringan pada musim kemarau (Sinuraya 2019). Pada tahun 2013, luas hutan di DAS Cisadane Hulu sekitar 21,7\%. Berdasarkan UU 41 Tahun 1999 Pasal 18 Ayat 1, luas kawasan hutan dalam setiap daerah aliran sungai (DAS) dan atau pulau, minimal $30 \%$ dari luas daratan. Dengan demikian, perubahan penggunaan lahan tersebut berpengaruh pada kapasitas simpan air di DAS Cisadane Hulu. Gangguan pada kapasitas simpan air pada DAS tersebut akan menyebabkan fungsi DAS sebagai pemasok air akan terganggu juga (Ahsoni 2008).

Sungai Cisadane merupakan sumber air baku utama bagi masyarakat Kota Bogor dan Kabupaten Bogor, baik untuk kegiatan domestik maupun nondomestik. Kebutuhan air di DAS Cisadanae Hulu dengan asumsi kebutuhan air untuk hidup layak sebesar $1.600 \mathrm{~m}^{3}$ air/kapita/tahun, maka kebutuhan air berdasarkan jumlah penduduk sebanyak 1.596 .690 jiwa pada tahun 2013 adalah sebesar $2.554,70 \times 10^{6}$ $\mathrm{m}^{3} /$ tahun. Dengan demikian, terjadi defisit air di DAS

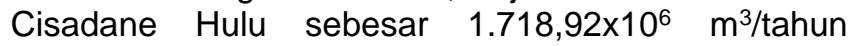
(Maulana 2016). Defisit air dalam DAS Cisadane Hulu akan semakin besar dengan peningkatan perkembangan jumlah penduduk dan laju pembangunan di Kota dan Kabupaten Bogor. Hal ini akan berdampak pada eksploitasi sumber daya air yang berlebih karena air telah memiliki nilai ekonomi dalam semua persaingan penggunaannya sehingga trend permintaan akan air menjadi lebih cepat dibandingkan dengan pertumbuhan suplainya (Seragelgin 1994). Bila terjadi eksploitasi maka kondisi tersebut akan menimbulkan konflik. Persaingan dalam penggunaan air telah memunculkan konflik terbuka antara penduduk dan pengelola industri air (Popi 2011). Peningkatan pertumbuhan kebutuhan air (domestik) untuk konsumsi masyarakat akan memberikan pemasalahan lahan dalam sistem hidrologi. Tekanan yang diberikan dapat bersifat internal pada ketersediaan air di DAS Cisadane Hulu maupun eksternal atau di luar DAS Cisadane Hulu. Dengan demikian, perencanaan penggunaan lahan yang optimal perlu disusun untuk dijadikan sebagai bahan pertimbangan dalam penentuan kebijakan pengelolaan DAS Cisadane Hulu agar ketersediaan air baku tetap terjaga. Penelitian ini bertujuan untuk mengkaji ketersediaan dan kebutuhan air, mengkaji neraca ketersediaan dan kebutuhan air, dan menyusun rekomendasi perencanaan pengelolaan lahan yang optimal di DAS Cisadane Hulu.

\section{METODE PENELITIAN}

\section{Lokasi Penelitian}

Penelitian ini dilaksanakan pada bulan Januari 2019-Mei 2020 di Hulu DAS Cisadane. Secara administrasi, wilayah DAS Cisadane Hulu masuk ke dalam wilayah Kota dan Kabupaten Bogor, Jawa Barat. Wilayah pada penelitian ini terbagi menjadi dua Daerah Tangkapan Air (DTA), yaitu DTA Cianteun dan DTA Cisadane Hulu, yang ditentukan dengan pertimbangan memiliki Stasiun Pengamat Arus Sungai (SPAS) yang berbeda. DTA Cianteun memiliki SPAS Batu Beulah dengan luas wilayah sebesar 17.301 ha dan DTA Cisadane Hulu memiliki SPAS Empang dengan luas 23.501 ha. Peta lokasi penelitian dapat dilihat pada Gambar 1.

\section{Bahan dan Alat}

Bahan-bahan yang digunakan berasal dari data primer dan data sekunder yang meliputi jenis data spasial, data numerik, data lapangan, dan data pendukung. Data spasial antara lain berupa peta administrasi DAS Cisadane, peta topografi yang diperoleh dari BPDASHL Citarum-Ciliwung, peta jenis tanah yang diperoleh dari BBSDL, citra SPOT 6 yang diperoleh dari LAPAN, peta RTRW Provinsi yang diperoleh dari Bappeda Provinsi Jawa Barat, peta RTKRHL DAS Cisadane yang diperoleh dari BPDASHL Citarum-Ciliwung, dan peta kawasan hutan yang diperoleh dari Direktorat Jenderal Planologi, Departemen Kehutanan. Data numerik meliputi data hidrologi yang terdiri atas data curah hujan yang diperoleh dari BMKG Bogor, untuk data debit sungai Cisadane diperoleh dari BBWS Ciliwung-Cisadane dan UPT PSDA Wilyah Ciliwung-Cisadane serta data BPS kecamatan dalam angka tahun 2018 dari BPS Kota Bogor dan BPS Kabupaten Bogor. Data-data lapangan meliputi data hasil analisis tanah dari pengambilan sampel di lapangan. Data pendukung berupa literatur dari hasil penelitian terdahulu. Peralatan yang digunakan dalam penelitian adalah seperangkat computer dan Microsoft office 2010, dan global position system (GPS), untuk analisis data digunakan perangkat lunak (software) ArcGIS 10.3, ring sampel tanah, printer, dan alat tulis kantor.

\section{Kebutuhan Air (Water Demand)}

Perhitungan kebutuhan air dikelompokkan menjadi, kebutuhan air domestik, kebutuhan air industri, kebutuhan air irigasi padi sawah, kebutuhan air 


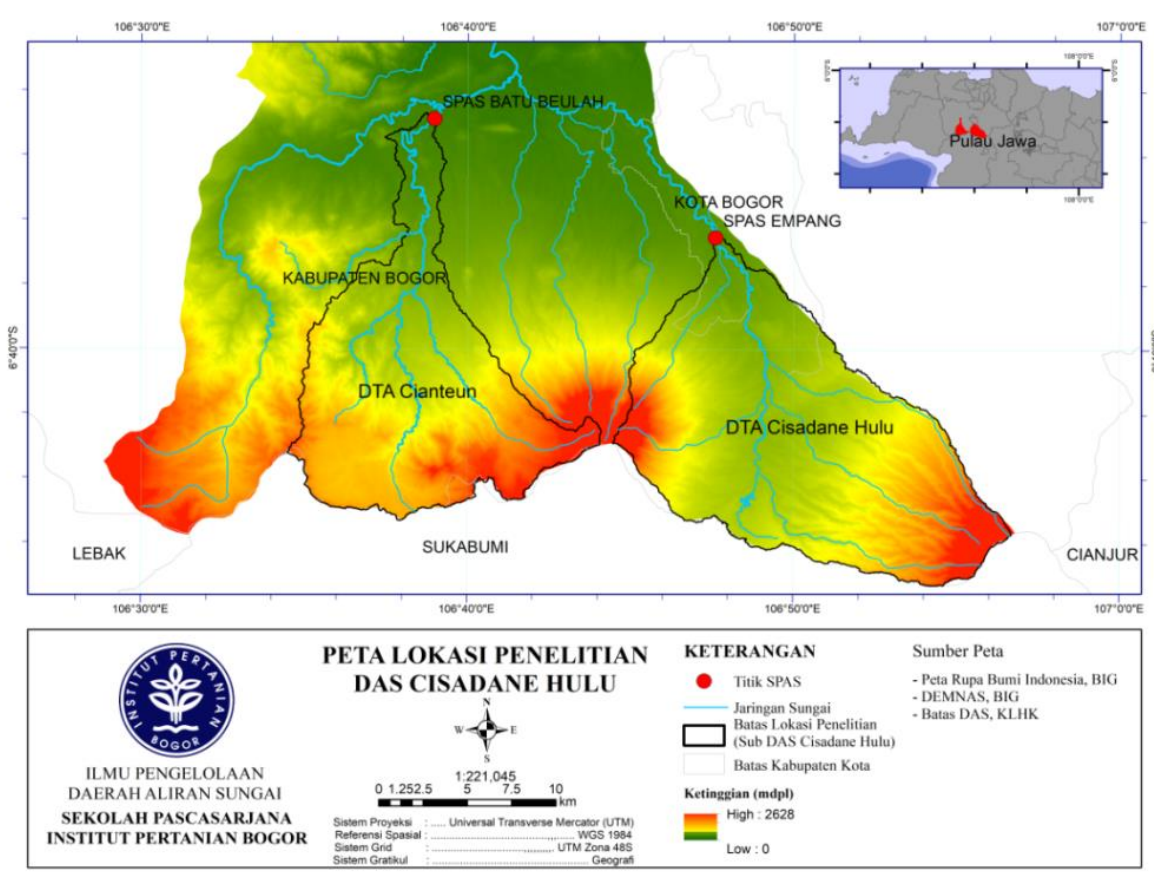

Gambar 1 Peta lokasi penelitian Daerah Aliran Sungai Cisadane.

perikanan, dan kebutuhan air peternakan. Metode perhitungan untuk memperoleh kebutuhan air menggunakan SNI 19-6728.1-2002.

Persamaan yang digunakan untuk menghitung kebutuhan air domestik adalah sebagai berikut:

$$
\mathrm{Q}_{\mathrm{DM}}=365 \text { harix }\left\{\frac{\mathrm{q}(\mathrm{u})}{1000} \times \mathrm{P}(\mathrm{u})+\frac{\mathrm{q}(\mathrm{r})}{1000} \times \mathrm{P}(\mathrm{r})\right\}
$$

\section{Keterangan:}

$\mathrm{QDM}_{\mathrm{DM}}=$ Kebutuhan air domestik (m³/tahun)

$\mathrm{q}(\mathrm{u})=$ Konsumsi air daerah perkotaan (L/kapita/hari)

$q(r)=$ Konsumsi air daerah perdesaan (liter/kapita/hari)

$\mathrm{P}(\mathrm{u})=$ Jumlah penduduk kota (jiwa)

$P(r)=$ Jumlah penduduk desa (jiwa)

Perhitungan kebutuhan air industri dihitung berdasarkan jumlah hari kerja dan jumlah tenaga kerja dengan menggunakan tiga jenis kelas industri (Purwanto 1995). Persamaan yang digunakan untuk menghitung kebutuhan air industri adalah sebagai berikut:

$$
Q_{I D}=H k(T k x Q i)
$$

\section{Keterangan:}

$Q_{\text {ID }}=$ Kebutuhan air industri ( $\mathrm{m}^{3} /$ tahun)

$\mathrm{Hk}=$ Jumlah hari kerja (tahun)

$\mathrm{Tk}=$ Jumlah tenaga kerja (jiwa)

Qi = Kebutuhan air skala industri ( $\mathrm{m}^{3} /$ hari).

Besarnya kebutuhan air irigasi dihitung berdasarkan persamaan sebagai berikut (SNI 6728.1 2015):

$$
Q I R=L x \text { It } x a
$$

Keterangan:

QIR = Kebutuhan air untuk mengairi sawah (m³/tahun)

$\mathrm{L}=$ Luas sawah (ha)

$\mathrm{I}_{\mathrm{t}}=$ Intensitas musim tanam dalam persen (\%) musim/tahun

$\alpha$ = Standar penggunaan air irigasi (1 L/detik/ha) $/ 0,001 \mathrm{~m} / \mathrm{de} / \mathrm{ha} \times 3600 \times 24 \times 120$ hari/musim

Kebutuhan air untuk perikanan dapat dihitung dengan menggunakan persamaan sebagai berikut:

$$
\mathrm{Qfp}=\mathrm{q}(\mathrm{fp}) / 1000 \times \mathrm{A}(\mathrm{fp}) \times 10000
$$

\section{Keterangan:}

$Q_{\mathrm{fp}}=$ Kebutuhan air untuk perikanan ( $\mathrm{m}^{3} /$ tahun)

$\mathrm{q}_{(\mathrm{fp})}=$ Kebutuhan air untuk pembilasan (L/hari/ha)

$A_{(\mathfrak{f p})}=$ Luas kolam tambak (ha).

Standar yang digunakan untuk menghitung kebutuhan air peternakan adalah SNI 19-6728.1 (2002) yang didasarkan pada hasil penelitian tentang sumber daya air nasional tahun 1992 dengan persamaan sebagai berikut:

$$
\begin{gathered}
\mathrm{QL}=365 \text { hari } x \mathrm{Q}(\mathrm{c} / \mathrm{b}) \times \mathrm{Q}(\mathrm{s} / \mathrm{g}) x \mathrm{Q}(\mathrm{po}) \times \mathrm{P}(\mathrm{c} / \mathrm{b}) x \\
\mathrm{P}(\mathrm{s} / \mathrm{g}) x \mathrm{P}(\mathrm{po})
\end{gathered}
$$

Keterangan:

$Q_{L}=$ Kebutuhan air untuk ternak ( $\mathrm{m}^{3} /$ tahun)

$Q_{(\mathrm{c} / \mathrm{b})}=$ Kebutuhan air untuk sapi/kerbau/kuda

(L/ekor/hari)

$Q_{(s / g)}=$ Kebutuhan air untuk domba/kambing (L/ekor/hari)

$Q_{\text {(po) }}=$ Kebutuhan air untuk unggas (L/ekor/hari)

$\mathrm{P}_{(\mathrm{c} / \mathrm{b})}=$ Jumlah sapi/kerbau/kuda (ekor)

$\mathrm{P}_{(\mathrm{s} / \mathrm{g})}=$ Jumlah domba/kambing (ekor)

$P_{(p o)}=$ Jumlah unggas (ekor). 
Kebutuhan air total di suatu DAS dapat diperoleh dengan menjumlahkan kebutuhan air dari 5 (lima) sektor peruntukan tersebut dengan persamaan sebagai berikut:

$$
Q_{\text {Total }}=Q_{D M}+Q_{I D}+Q_{I G}+Q_{F P}+Q_{L}
$$

Keterangan:

$\begin{array}{ll}Q_{\text {Total }} & =\text { Kebutuhan air total (m³/tahun) } \\ Q_{D M} & =\text { Kebutuhan air domestik (m³/tahun) } \\ Q_{\text {ID }} & =\text { Kebutuhan air industri (m³/tahun) } \\ Q_{\text {IG }} & =\text { Kebutuhan air sawah (m³tahun) } \\ Q_{F P} & =\text { Kebutuhan air perikanan (m³/tahun) } \\ Q_{L} & =\text { Kebutuhan air peternakan (m³/tahun). }\end{array}$

\section{Ketersediaan Air (Water Supply)}

Ketersediaan air pada penelitian ini dihitung berdasarkan debit andalan dengan menggunakan metode Mock. Model Mock merupakan metode penghitungan aliran sungai yang diperkenalkan oleh Dr.F.J.Mock pada tahun 1973. Tahapan perhitungan (Dirjen Pengairan 1985) adalah sebagai berikut:

$$
\begin{gathered}
\text { Evapotranspirasi aktual }\left(\mathrm{E}_{\mathrm{a}}\right) \\
\Delta \mathrm{E}=\mathrm{ET}_{0} \frac{m}{20}(18-\mathrm{n})
\end{gathered}
$$

Keterangan:

$\Delta \mathrm{E}=$ Perubahan evapotranspirasi potensial dengan aktual ( $\mathrm{mm} /$ bulan)

$E T_{0}=$ Evapotranspirasi potensial ( $\mathrm{mm} /$ bulan)

$\mathrm{m}$ = Proporsi permukaan lahan yang tidak tertutup oleh vegetasi (\%)

$\mathrm{n} \quad=$ Jumlah hari hujan

Nilai $m$ merupakan proporsi permukaan lahan yang tidak tertutup oleh vegetasi atau exposed surface $(\mathrm{m})$, kapasitas kelembapan tanah, faktor infiltrasi dan resesi limpasan. Exposed surface $(\mathrm{m})$ adalah proporsi permukaan luar yang tidak tertutupi oleh tumbuhan hijau pada musim kering. Berdasarkan exposed surface, Mock membagi daerah permukaan bumi menjadi 3 bagian, yaitu hutan primer dan sekunder $(0$ $10 \%)$, daerah erosi $(10-40 \%)$, serta daerah ladang pertanian (30-50\%). Parameter yang disarankan proporsi permukaan lahan yang tidak tertutup vegetasi oleh Mock adalah 0-50\%. Asumsi proporsi permukaan luar yang tidak tertutupi tumbuhan hijau pada musim kering mempunyai evapotranspirasi yang tidak berarti pada hari-hari permukaan kering (Fakhrurrazi 2012).

$$
\begin{gathered}
\text { Penyimpanan kelembapan tanah (SMS) } \\
\mathrm{SMS}=\mathrm{ISM}+\mathrm{Re}-\mathrm{E}
\end{gathered}
$$

Keterangan:

$$
\begin{aligned}
\mathrm{ISM}= & \text { Kelembapan tanah awal }(\mathrm{mm}) \text { merupakan } \\
& \text { soil moisture capacity }(\mathrm{SMC}) \text { bulan } \\
& \text { sebelumnya } \\
\mathrm{Re}= & \text { Curah hujan }(\mathrm{mm}) \\
\mathrm{E} & =\text { Evapotranspirasi }(\mathrm{mm} / \mathrm{bulan})
\end{aligned}
$$

$$
\text { Kelebihan air (WS) }
$$

$$
W S=I S M+R e-E-S M C
$$

Keterangan:

$$
\begin{array}{ll}
\mathrm{ISM} & =\text { Kelembapan tanah awal }(\mathrm{mm}) \\
\mathrm{Re} & =\text { Curah hujan }(\mathrm{mm}) \\
\mathrm{E} & =\text { Evapotranspirasi (mm/bulan) } \\
\mathrm{SMC} & =\text { Kapasitas kelembapan tanah. }
\end{array}
$$

$$
\begin{aligned}
& \text { Infiltrasi (inf) } \\
& \text { Inf = WS } \times \text { IF }
\end{aligned}
$$

Keterangan:

WS = Kelebihan air

IF $\quad=$ Faktor infiltrasi

Penyimpanan air tanah pada akhir bulan (G.STORt) G. STORt $=$ G.STOR(t-1) $\times R c+((1+R c) / 2) \times \inf$

Keterangan:

G. STORt = Daya tampung tanah pada awal

G.STOR(t-1) = Penyimpanan air tanah pada akhir

bulan ( $\mathrm{mm} / \mathrm{bulan}$ )

$\mathrm{Rc} \quad=$ Konstanta resesi limpasan

Inf $\quad=$ Infiltrasi

Limpasan dasar (Qbase)

Qbase $=$ inf - G.STORt + G.STOR $(t-1)$

Keterangan:

Inf = Infiltrasi

G. STORt = Daya tampung tanah pada awal bulan ( $\mathrm{mm} /$ bulan)

G.STOR(t-1) = Penyimpanan air tanah pada akhir bulan ( $\mathrm{mm} /$ bulan)

Limpasan permukaan (Qdirect)

Qdirect $=$ WS $\times(1-I F)$

Keterangan:

WS = Kelebihan air

$\mathrm{IF} \quad=$ Faktor infiltrasi

Limpasan hujan sesaat (Qstrom) Qstrom $=$ Re $\times$ PF

Keterangan:

$\mathrm{PF} \quad=$ Faktor persentase

$\mathrm{Re} \quad=$ Curah hujan $(\mathrm{mm})$

\section{Total limpasan (Qtotal)}

Total run off (TRO) yang merupakan komponenkomponen pembentuk debit sungai (stream flow) adalah jumlah antara base flow, direct run off, dan storm run off, atau dengan persamaan sebagai berikut: QTotal $=$ Qbase + Qdirect + Qstrom

\section{Debit sungai (Qs)}

Total run off ini dinyatakan dalam $\mathrm{mm} / \mathrm{bulan}$. Dengan demikian, jika TRO dikalikan dengan 
catchment area (luas daerah tangkapan air) dalam $\mathrm{km}^{2}$ dengan suatu angka konversi tertentu didapatkan besaran debit dalam $\mathrm{m}^{3} /$ detik, atau dengan persamaan di bawah ini:

$$
\text { QS = Qtotal } \times A
$$

Keterangan:

$\mathrm{A}=$ Luas DAS $\left(\mathrm{km}^{2}\right)$

\section{Neraca Air}

Neraca air suatu DAS merupakan keseimbangan antara jumlah air yang masuk (inflow) dan keluar (outflow) di suatu wilayah DAS untuk suatu periode tertentu dari proses sirkulasi air. Apabila neraca air positif maka tidak terjadi kekurangan air (surplus), dan apabila neraca air negatif maka mengindikasikan adanya kekurangan air (defisit) pada DAS tersebut. Untuk mengetahui neraca air DAS Cisadane Hulu dilakukan perhitungan menggunakan persamaan:

$$
\text { QKetersediaan }- \text { QKebutuhan }=\Delta S
$$

\section{Skenario Perencanaan Penggunaan Lahan}

Perencanaan penggunaan lahan untuk konservasi sumber daya air di Hulu DAS Cisadane dilakukan melalui model hidrologi dengan cara memprediksi total limpasan menggunakan metode Mock. Skenario perencanaan penggunaan lahan dilakukan untuk mendapatkan rekomendasi perencanaan pengelolaan lahan berbasis sumber daya air yang dapat menghindari terjadinya degradasi lahan, meningkatkan laju infiltrasi, mengurangi total limpasan, melindungi infrastruktur di bagian hilir, dan sebagai upaya pelestarian sumber daya air sehingga dapat memberikan sumbangan besar pada ketersediaan air guna memenuhi kebutuhan air di Hulu Cisadane. Pemilihan skenario terbaik pada penelitian ini berdasarkan nilai defisit neraca air pada bulan kemarau terendah. Adapun skenario dalam penelitian ini adalah: Skenario 1 menggambarkan kondisi biofisik DAS Cisadane Hulu pada saat ini (existing) dengan luas penggunaan lahan pada tahun 2018. Skenario 2 Mengimplementasikan penggunaan lahan sesuai dengan rencana tata ruang wilayah (RTRW). Skenario 3 mengimplementasikan berdasarkan RTkRHL (Rencana Teknik Rehabilitasi Hutan dan Lahan). Skenario 4 mengimplementasikan berdasarkan penggunaan Lahan sesuai dengan Peta Kawasan Hutan Negara. Skenario 5 merupakan penerapan penggunaan lahan dengan menggabungkan skenario RTRW, RTkRHL, dan Kawasan Hutan. Skenario-6 merupakan penerapan penggunaan lahan dengan menggabungkan skenario RTRW, RTkRHL, Kawasan Hutan, dan Agroforestry.

\section{HASIL DAN PEMBAHASAN}

\section{Kebutuhan Air (Water Demand)}

Kebutuhan air total dari penelitian ini diperoleh dengan pendekatan persentase wilayah administrasi yang masuk ke dalam wilayah penelitian dikalikan dengan jumlah keseluruhan kebutuhan air dari setiap sektor (kebutuhan air rumah tangga, kebutuhan air industri, mengairi lahan sawah irigasi, mengisi kolam budi daya ikan air tawar, dan untuk kebutuhan air peternakan). Kebutuhan air total diperoleh dari kebutuhan air untuk semua keperluan yang masuk ke dalam wilayah DTA Cianteun dan Cisadane Hulu. Karakterisasi kebutuhan air untuk masing-masing sektor dilakukan berdasarkan data BPS dan dinas terkait pada tahun 2018.

Berdasarkan analisis kebutuhan, total kebutuhan air di DTA Cianteun adalah sebanyak 108.952.291 $\mathrm{m}^{3} /$ tahun. Kebutuhan air terbesar digunakan untuk keperluan industri sebesar 52.524.288 $\mathrm{m}^{3} /$ tahun, sedangkan kebutuhan air terendah untuk sektor perikanan sebanyak $415.239 \mathrm{~m}^{3} /$ tahun. Sementara itu, permintaan kebutuhan air terbanyak pada tahun 2018 di DTA Cisadane Hulu adalah sektor industri, yaitu sebanyak $211.081 .728 \mathrm{~m}^{3} /$ tahun. Kebutuhan air industri pada penelitian ini merupakan jenis usaha industri yang terdapat dalam wilayah penelitian yang termasuk ke dalam klasifikasi jenis usaha industri skala menengah dengan kategori usaha industri terbanyak adalah industri makanan dan minuman. Pemakaian air terendah ditemukan pada sektor perikanan, yaitu sebesar $337.530 \mathrm{~m}^{3} /$ tahun, sedangkan kebutuhan air secara total di DTA Cisadane Hulu mencapai 308.733.311 $\mathrm{m}^{3} /$ tahun. Perhitungan kebutuhan air (water demand) total di DTA Cianteun dan DTA Cisadane Hulu pada tahun 2018 dapat dilihat pada Tabel 1.

\section{Ketersediaan Air (Water Supply)}

Ketersediaan air di Hulu DAS Cisadane dihasilkan dari metode Mock dengan parameterparameter yang disarankan oleh Mock, yaitu proporsi permukaan lahan yang tidak tertutup oleh vegetasi atau exposed surface $(\mathrm{m})$, kapasitas kelembapan tanah, faktor infiltrasi, dan resesi limpasan (Fakhrurrazi 2012). Faktor-faktor yang memengaruhi penentuan debit sungai dengan metode Mock adalah: berdasarkan hasil analisis citra SPOT diketahui bahwa

Tabel 1 Perbandingan hasil skenario dari aspek hidrologi Daerah Tangkapan Air (DTA) Cisadane Hulu Tahun 2018

\begin{tabular}{lcc}
\hline \multicolumn{1}{c}{ Sektor kebutuhan air } & DTA Cianteun $\left(\mathrm{m}^{3} /\right.$ tahun) & DTA Cisadane Hulu $\left(\mathrm{m}^{3} /\right.$ tahun $)$ \\
\hline Rumah tangga (Domestik) & 13.109 .862 & 44.335 .927 \\
Irigasi & 41.044 .919 & 52.080 .558 \\
Perikanan & 415.239 & 337.530 \\
Peternakan & 1.857 .983 & 897.569 \\
Industri & 52.524 .288 & 211.081 .728 \\
\hline Total kebutuhan air & 108.952 .291 & 308.733 .311 \\
\hline
\end{tabular}


proporsi permukaan lahan yang tidak tertutup oleh vegetasi $(\mathrm{m})$ pada saat ini (exsisting) adalah $25,71 \%$ pada DTA Cianteun dan $30,35 \%$ pada DTA Cisadane Hulu. Parameter lain yang digunakan dalam penelitian ini adalah kapasitas kelembapan tanah sebesar 194,17 $\mathrm{mm}$ dan tampungan tanah permulaan sebesar 138,37 yang didasarkan pada faktor kelengasan tanah pada DTA Cianteun, sedangkan di DTA Cisadane Hulu, kapasitas kelembapan tanah adalah sebesar 149,18 $\mathrm{mm}$ dan tampungan tanah permulaan sebesar 141,96. Lengas tanah diperoleh dari hasil pengambilan sampel tanah yang dilakukan uji laboratorium berdasarkan metode hydrometer, selanjutnya dalam penentuan tekstur tanah dengan metode diagram segitiga tekstur tanah. Hasil uji laboratorium ditemukan bahwa kelas tanah di lokasi penelitian adalah kelas tanah lempung berpasir sampai kelas tanah liat, dengan kandungan liat antara 18,3-85,2\%, kandungan pasir antara 6,2$58,2 \%$, serta kandungan debu antara 7,1-55\%. Adapun koefisien infiltrasi adalah 0,4 dan konstanta resesi limpasan adalah 0,6.

Validasi data adalah proses evaluasi model untuk mendapatkan gambaran tentang tingkat ketidakpastian yang dimiliki oleh suatu model dalam memprediksi proses hidrologi (Indarto 2010). Adapun hasil proses validasi dengan membandingkan data debit observasi dengan debit simulasi model selama periode 10 tahun (Januari 2009-Desember 2018) dihasilkan nilai NSE sebesar 0,44 (kategori memenuhi) dan nilai koefisien determinasi $\left(R^{2}\right)$ sebesar 0,69 pada DTA Cianteun. Nilai $N S E \geq 0,36$ dan $R^{2} \geq 0,6$ merupakan nilai yang dapat diterima (Motovilov et al. 1999). Berdasarkan nilai tersebut, maka model Mock sudah cukup akurat untuk digunakan. Hidrograf debit simulasi dan observasi hasil validasi bulanan disajikan pada Gambar 2. Sementara itu, hasil validasi pada DTA Cisadane Hulu menunjukkan nilai NSE sebesar 0,53 dengan nilai determinasi $\left(R^{2}\right)$ sebesar 0,77 sehingga dengan hasil tersebut model dikategorikan diterima dan dapat digunakan dalam penyusunan skenario selanjutnya (Gambar 3).

Dalam menganalisis ketersediaan air (Water supply) digunakan data debit sungai. Ketersediaan air bulanan Sungai Cisadane dihitung dengan transformasi data hujan dan berdasarkan estimasi karakteristik daerah aliran sungai dengan menggunakan data hujan selama 10 tahun (sesuai data yang tersedia). Setelah didapat data ketersediaan air bulanan pada tahun tertentu dengan hasil validasi terpenuhi maka dilanjutkan dengan penentuan debit andalan dengan menggunakan metode bulan dasar perencanaan dan probabilitas masing-masing data

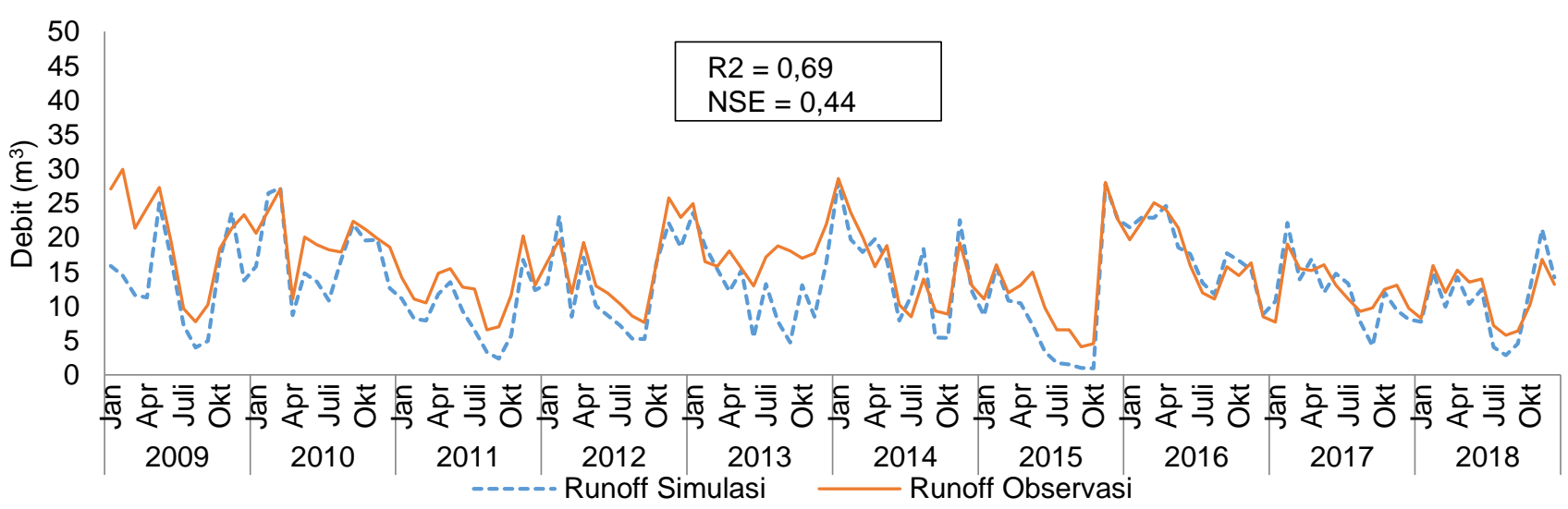

Gambar 2 Hidrograf debit simulasi dan observasi validasi Daerah Tangkapan Air (DTA) Cianteun (NSE: 0,44).

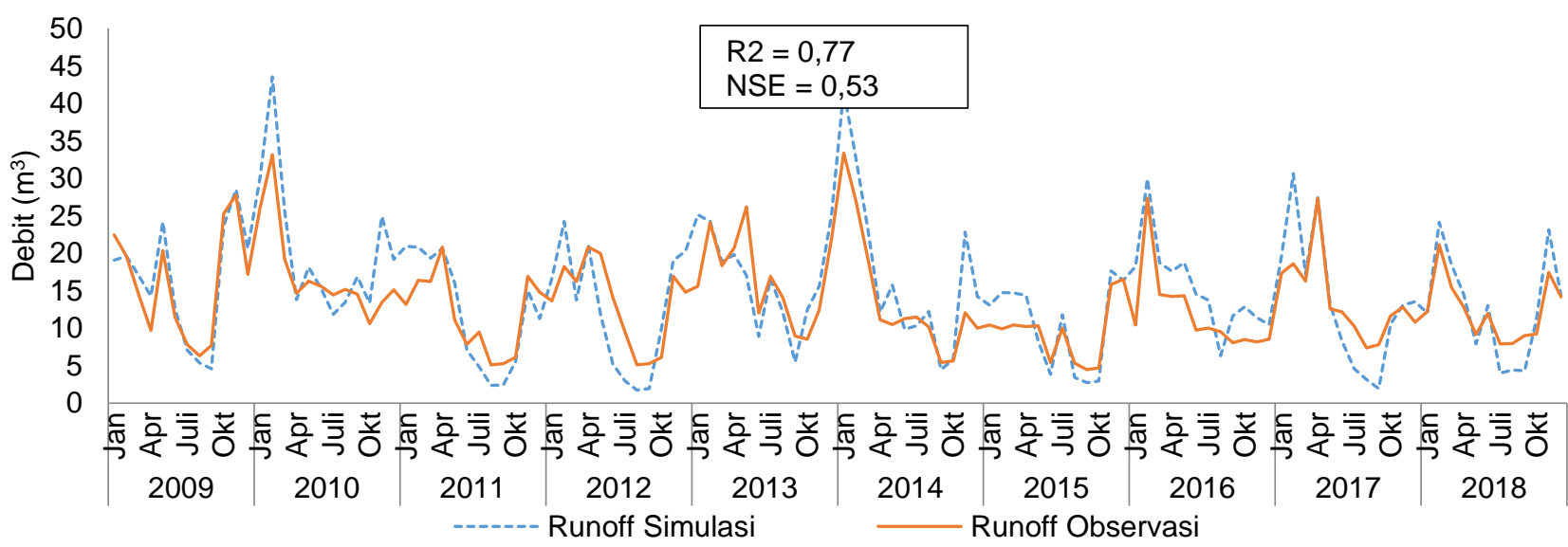

Gambar 3 Hidrograf debit simulasi dan observasi validasi Daerah Tangkapan Air (DTA) Cisadane Hulu (NSE: 0,53). 
dihitung dengan persamaan Weibull (Limantara 2010), di mana $Q$ adalah debit yang terjadi dengan tingkat kepercayaan $80 \%$ (probabilitas).

Ketersediaan air probabilitas terpenuhi $80 \%$ pada DTA Cianteun dikonversikan ke satuan volume per tahun sebesar $248.584 .986 \mathrm{~m}^{3} /$ tahun. Debit andalan maksimum pada DTA Cianteun terjadi pada bulan Februari, yaitu sebesar 14,6 m³/detik (35.207.776 m³), sedangkan debit andalan minimum terjadi pada bulan September, yaitu sebesar 2,8 $\mathrm{m}^{3} /$ detik $\left(7.364 .345 \mathrm{~m}^{3}\right)$. Durasi kurva aliran ketersediaan air bulanan Sungai Cianteun berdasarkan karakteristik DAS dengan data hujan 10 tahun, debit andalan bulanan yang diperoleh dari data 10 tahun (2009-2018) di DTA Cianteun dengan kemungkinan terpenuhi $80 \%$ berkisar $Q=2,8$ $\mathrm{m}^{3} /$ detik sampai dengan $\mathrm{Q}=14,6 \mathrm{~m}^{3} /$ detik.

Ketersediaan air bulanan sungai pada DTA Cisadane Hulu berdasarkan karakteristik DAS dengan data hujan 10 tahun, debit andalan bulanan yang diperoleh dari data 10 tahun (2009-2018) di DTA Cisadane Hulu dengan kemungkinan terpenuhi $80 \%$ berkisar $Q=2,0 \mathrm{~m}^{3} /$ detik sampai dengan $\mathrm{Q}=19,8$ $\mathrm{m}^{3} /$ detik. Total ketersediaan air di DTA Cisadane Hulu adalah sebesar $301.882 .316 \mathrm{~m}^{3} /$ tahun.

\section{Neraca Air}

Analisis neraca air (water balance) ketersediaan dan kebutuhan air pada penelitian ini dilakukan guna mengetahui tingkat surplus dan defisit air. Neraca air pada penelitian ini dihitung berdasarkan pendekatan ketersediaan air permukaan (water supply) yang berasal dari debit andalan dengan periode 10 tahun (2009-2018) dan berdasarkan kebutuhan air (water demand) dari 5 (lima) sektor kegiatan. Hasil neraca air membuktikan bahwa DTA Cianteun memperoleh nilai surplus sebesar $139.632 .695 \mathrm{~m}^{3} /$ tahun yang diperoleh dari analisis kebutuhan air pada tahun 2018, yaitu sebesar 108.952.291 $\mathrm{m}^{3} /$ tahun dikurangi dengan hasil analisis ketersediaan air yang dihitung berdasarkan debit andalan selama periode 10 tahun (2009-2018) di DTA Cianteun, yaitu sebesar 248.584.986 $\mathrm{m}^{3} /$ tahun. Gambar 4 menunjukkan bahwa selisih supply-demand untuk pemanfaatan air di DTA Cianteun pada bulan Januari, Februari, Maret, April, Mei, Juni, Oktober, November, dan Desember masih terpenuhi (surplus). Ketersediaan air pada bulan Agustus dan September terjadi defisit air. Hal ini disebabkan karena pada bulan Agustus sampai bulan September terjadi penurunan curah hujan sehingga pasokan air yang ada tidak dapat memenuhi kebutuhan.

Ketersediaan air yang dihitung berdasarkan debit andalan dengan periode 10 tahun (2009-2018) di DTA Cisadane Hulu adalah sebesar $301.637 .711 \mathrm{~m}^{3} /$ tahun. Kebutuhan air DAS Cisadane Hulu pada tahun 2018 dari 5 sektor sebanyak 308.733.311 $\mathrm{m}^{3} /$ tahun. Kebutuhan air di DTA Cisadane Hulu tidak dapat dipenuhi dari ketersediaan air yang ada sehingga terjadi defisit sebesar $-6.850 .995 \mathrm{~m}^{3} /$ tahun. Berdasarkan perhitungan neraca air bulanan, distribusi air tidak merata sepanjang tahun. Ketersediaan air terendah di DTA Cisadane Hulu terjadi pada bulan September, yaitu sebesar $5.265 .859 \mathrm{~m}^{3}$, sehingga terjadi defisit air sebesar $-20.109 .482 \mathrm{~m}^{3}$. Defisit air pada bulan Mei, Juni, Juli, Agustus, September, dan Oktober masing-masing sebanyak -2.172.477, $10.956 .545,-15.244 .115, \quad-19.463 .066, \quad-20.109 .482$ dan $-11.287 .401 \mathrm{~m}^{3} / \mathrm{bulan}$. Jumlah defisit pasokan air pada bulan Juni-Oktober mencapai sebesar $79.233 .085 \mathrm{~m}^{3}$. Defisit ini diharapkan dapat terpenuhi dari hasil skenario yang disusun. Grafik selisih supplydemand disajikan pada Gambar 5.

\section{Skenario Perencanaan Penggunaan Lahan}

Perencanaan penggunaan lahan untuk konservasi sumber daya air di DTA Cianteun dan DTA Cisadane Hulu dilakukan melalui pemodelan hidrologi dengan cara memprediksi total limpasan menggunakan metode Mock. Penyusunan rekomendasi pengelolaan

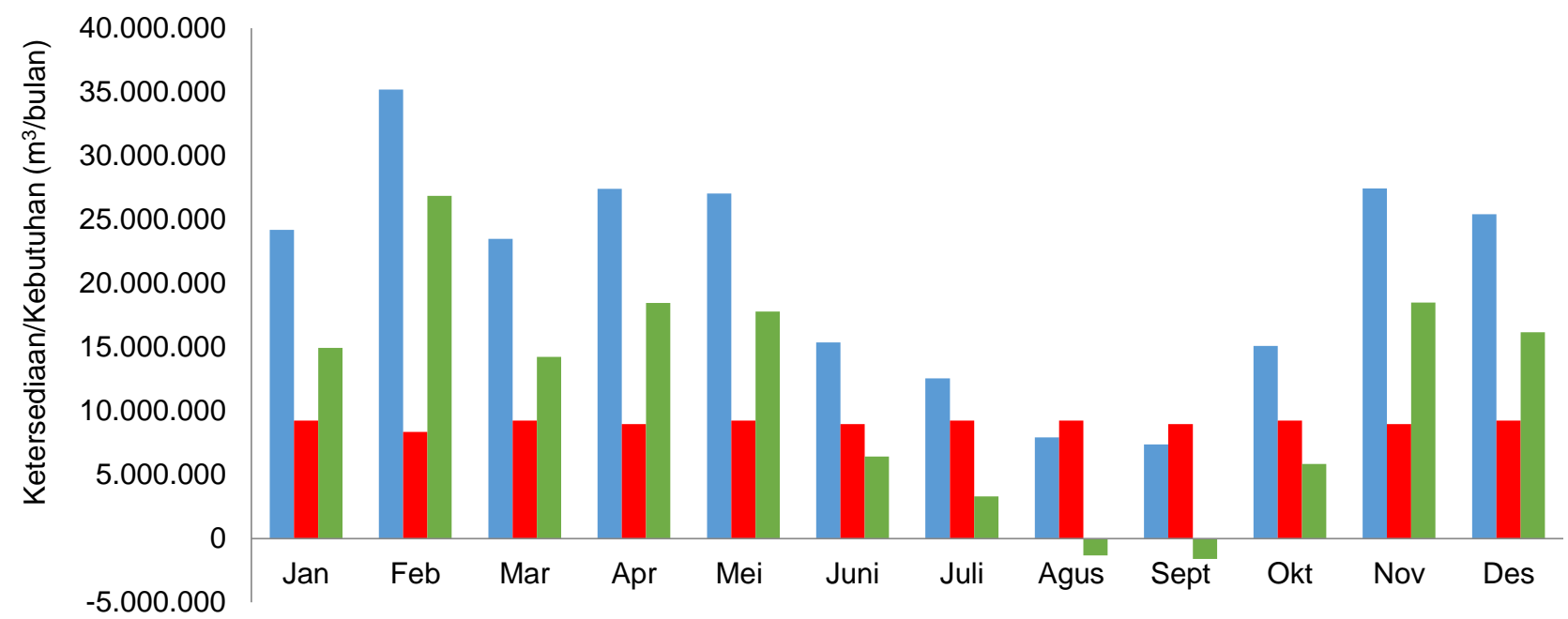

Gambar 4 Grafik neraca air rerata (supply-demand) di Daerah Tangkapan Air (DTA) Cianteun pada tahun 2009-2018. 


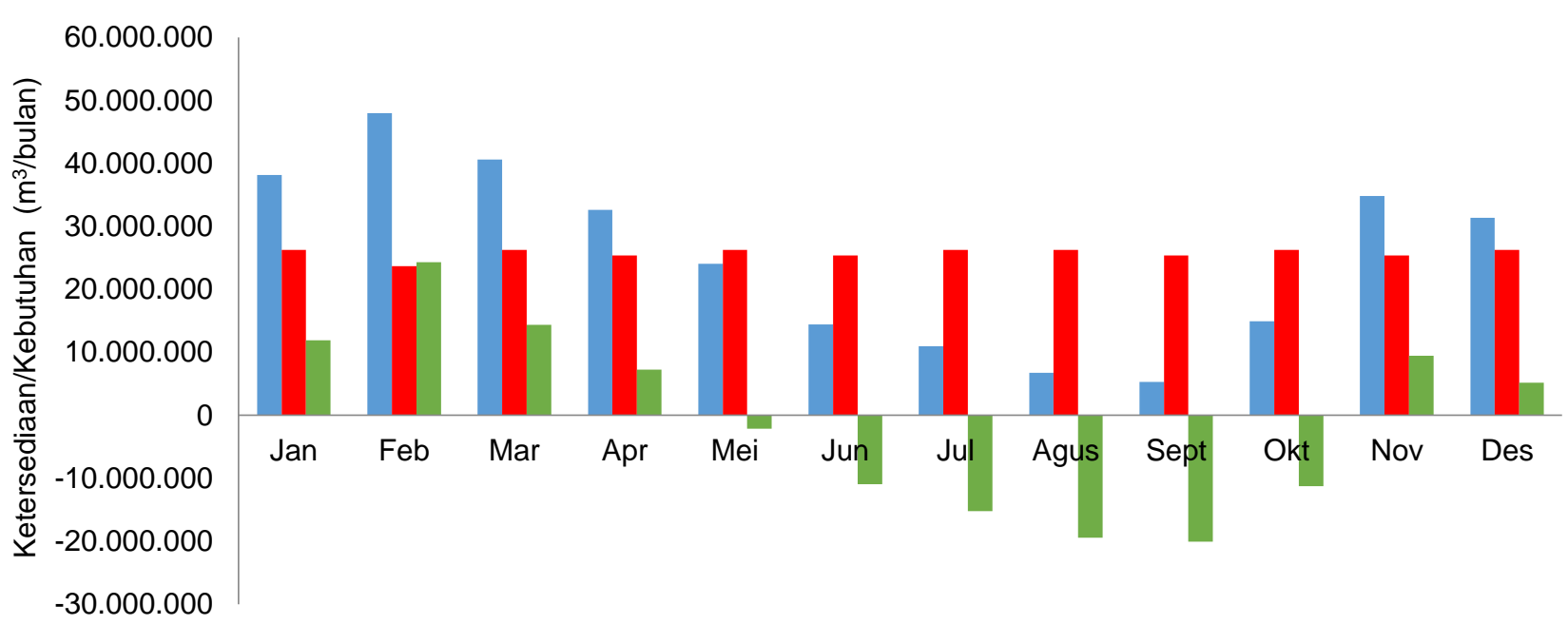

Gambar 5 Grafik neraca air rerata (supply-demand) di Daerah Tangkapan Air (DTA) Cisadane Hulu pada tahun 2009-2018.

didasarkan pada hasil skenario perencanaan penggunaan lahan. Aspek utama dalam pemilihan skenario adalah berdasarkan nilai water balance dengan menghasilkan defisit yang rendah dan mudah diterapkan serta aplicable di daerah penelitian maka akan menjadi skenario terbaik. Informasi ini sangat penting dalam perencanaan pengelolaan DAS yang lebih baik, agar cadangan air DAS mampu ditingkatkan sehingga dapat ditentukan kegiatan-kegiatan yang dapat menyeimbangi antara ketersediaan air dan kebutuhan air, bahkan diharapkan mampu meningkatkan cadangan air di DAS (Nugroho et al. 2009).

Penggunaan lahan berbagai skenario yang diperoleh dari overlay (tumpang tindih) antara peta penggunaan lahan, peta fungsi kawasan hutan, dan peta ijin Hkm. Setelah dilakukan overlay pada petapeta tersebut, terjadi perubahan penggunaan lahan. Perubahan penggunaan lahan pada skenario akan memengaruhi nilai parameter Mock, yaitu exposured surface, evapotranspirasi aktual, koefisien infiltrasi, dan SMC tertimbang, seperti pada Tabel 1. Hasil simulasi pada setiap skenario penggunaan lahan memperlihatkan adanya perubahan parameter yang berhubungan dengan karakteristik hidologi di DTA Cianteun maupun DTA Cisadane Hulu. Skenario 1 dengan penggunaan lahan eksisting memiliki faktor $m$ berkisar 26,04-30,36\%, yang menggambarkan bahwa proporsi permukaan lahan yang tidak tertutup oleh vegetasi pada skenario 1 relatif besar. Sementara itu, pada skenario 6 dengan penerapan penggunaan lahan RTRW, RTkRHL, Kawasan Hutan dan Agroforestry pada lahan pertanian dapat menurunkan proporsi permukaan lahan yang tidak tertutupi oleh vegetasi menjadi relatif kecil dengan nilai m berkisar 8,94\% hingga $13,95 \%$. Perencanaan penggunaan lahan yang baik pada skenario 6 memberikan dampak pada parameter kapasitas kelembapan tanah (SMC) yang mencapai $309 \mathrm{~mm}$ di DTA Cianteun menunjukkan bahwa tanah memiliki kemampuan menyerap air yang tinggi. Tanah yang memiliki kemampuan menyerap air tinggi memberikan nilai faktor infiltrasi (IF) pada skenario 6 sebesar 0,55 di DTA Cianteun dan 0,57 di DTA Cisadane Hulu. Perbandingan perubahan parameter Mock yang dipengaruhi oleh penggunaan lahan setiap skenario di DTA Cianteun dan Cisadane Hulu dapat dilihat pada Tabel 2.

Simulasi perubahan penggunaan lahan dilakukan untuk mendapatkan model penggunaan lahan yang terbaik untuk kondisi DTA Cianteun dan Cisadane Hulu. Simulasi skenario 6 menunjukkan bahwa penggunaan lahan pertanian merupakan salah satu faktor yang berpengaruh nyata pada penurunan total limpasan. Penerapan penggunaan lahan yang optimal oleh berbagai stakeholder mampu menurunkan defisit yang signifikan pada bulan kemarau di DTA Cisadane Hulu serta meningkatkan ketersediaan air pada DTA Cianteun sehingga memperoleh nilai surplus. Model perencanaan penggunaan lahan untuk konservasi sumber daya air yang tepat dan sesuai dengan kondisi DTA Cianteun dan Cisadane Hulu adalah dengan penerapan metode agroforestry dan peran serta stakeholder yang optimal, seperti tergambar pada skenario 6.

Penyusunan skenario perencanaan penggunaan lahan yang terjadi akan menentukan besaran nilai parameter pada model Mock. Selanjutnya akan memengaruhi total limpasan (debit). Total limpasan dihasilkan dari masing-masing skenario 1, skenario 2, skenario 3, skenario 4, skenario 5 , dan skenario 6 di DTA Cianteun berturut-turut sebesar 1.952,02; $1.935,83 ; 1.942,83 ; 1.941,85 ; 1925,26$; dan 1917,02 $\mathrm{mm} /$ tahun. Skenario yang disusun menunjukkan bahwa semakin baik komposisi penggunaan lahan akan menurunkan total limpasan air dan meningkatkan limpasan dasar dan meningkatkan perubahan simpanan air tanah (storage). Simpanan air tanah ini diharapkan akan keluar pada bulan-bulan kering dan dapat memenuhi kebutuhan air pada musim kemarau.

Limpasan dasar yang dihasilkan di DTA Cisadane Hulu dari masing-masing skenario-1, skenario-2, skenario-3, scenario-4. Scenario-5, dan skenario-6 
berturut-turut sebesar 638,$49 ; 727,16 ; 668,95 ; 686,22$ 732,75; dan 749,69 mm/tahun. Perubahan proporsi setiap penggunaan lahan pada suatu DAS akan menentukan besarnya nilai exposed surface $(\mathrm{m})$ yang akan memengaruhi penurunan limpasan dan peningkatan kapasitas infiltrasi. Total limpasan dihasilkan dari masing-masing skenario 1 , skenario 2 , skenario 3 , skenario 4 , skenario 5 , dan skenario 6 di DTA Cisadane Hulu berturut-turut sebesar 1.677,81; $1.643,81 ; 1.674,03 ; 1.672,1 ; 1.631,85 ;$ dan $1.627,66$ $\mathrm{mm} /$ tahun. Berdasarkan hasil simulasi dari 6 skenario, skenario 6 merupakan skenario dengan penggunaan lahan yang terbaik dari karakteristik hidrologi. Skenario yang disusun menunjukkan bahwa semakin baiknya kompisisi pengunaan lahan akan menurunkan limpasan air dan meningkatkan limpasan dasar pada DTA Cisadane Hulu.

Ketersediaan air pada DTA Cianteun dengan simulasi 6 skenario menunjukkan hasil yang surplus dalam pemenuhan kebutuhan. Jumlah volume air tahunan yang dihasilkan skenario-1, skenario-2, skenario-3, skenario-4, skenario-5, dan skenario-6 berturut-turut adalah sebesar 337.711.627; 334.909.351; 336.121.547; 335.951.228; 333.080.596; dan $331.654 .850 \mathrm{~m}^{3}$ /tahun (Tabel 3). Surplus tahunan tidak berarti DTA Cianteun tidak mengalami kekeringan pada musim kemarau (Mei hingga September). Hasil dari simulasi skenario 1 hingga 6 yang terlihat pada Gambar 6 menunjukkan bahwa DTA Cianteun mengalami defisit hanya pada bulan Agustsus. Defisit tertinggi dengan penerapan skenario 1 sebesar $-1.550 .322 \mathrm{~m}^{3} /$ bulan. Pasokan air pada bulan kemarau (Mei hingga September) tertinggi diperoleh dengan penerepan skenario-6, yaitu sebesar 106.138.168 $\mathrm{m}^{3}$ dengan hasil neraca air bulan kemarau sebesar $60.467 .756 \mathrm{~m}^{3}$, sehingga penerapan skenario 6 (menggabungkan peta RTRW, RTkRHL, Kawasan Hutan, dan penambahan Agroforestry) menunjukkan nilai surplus.

Volume air tahunan pada DTA Cisadane Hulu yang dihasilkan skenario-1, skenario-2, skenario-3, skenario-4, skenario-5, dan skenario-6 berturut-turut adalah sebesar 394.309.521; 386.319.912; 393.421.431; 392.977.485; 383.508.079; dan

Tabel 2 Perbandingan perubahan parameter Mock yang dipengaruhi oleh penggunaan lahan setiap skenario di Daerah Tangkapan Air (DTA) Cianteun dan Cisadane Hulu

\begin{tabular}{|c|c|c|c|c|c|c|c|c|c|c|c|c|}
\hline \multirow{2}{*}{ Parameter } & \multicolumn{6}{|c|}{ Skenario di DTA Cianteun } & \multicolumn{6}{|c|}{ Skenario DTA Cisadane Hulu } \\
\hline & 1 & 2 & 3 & 4 & 5 & 6 & 1 & 2 & 3 & 4 & 5 & 6 \\
\hline $\begin{array}{l}\text { Exposed } \\
\text { Surface }(\mathrm{m})\end{array}$ & 26,04 & 15,58 & 25,81 & 19,72 & 14,94 & 8,94 & 30,36 & 20,00 & 30,08 & 28,00 & 17,96 & 13,95 \\
\hline Ea (mm/tahun) & 1386 & 1399 & 1386 & 1394 & 1400 & 1408 & 1381 & 1394 & 1381 & 1384 & 1396 & 1401 \\
\hline IF & 0,40 & 0,47 & 0,41 & 0,45 & 0,49 & 0,55 & 0,40 & 0,50 & 0,43 & 0,45 & 0,52 & 0,57 \\
\hline SMC & 194 & 257 & 196 & 238 & 265 & 309 & 149 & 226 & 152 & 164 & 230 & 270 \\
\hline
\end{tabular}

Keterangan: $\mathrm{Ea}=$ Evapotransiprasi actual, IF = Infiltras, dan SMC =Soil Mositure Capacity.

Tabel 3 Perbandingan hasil berbagai skenario dengan model Mock di Daerah Tangkapan Air (DTA) Cianteun dan Cisadane Hulu $\left(\mathrm{m}^{3}\right)$

\begin{tabular}{crrrrrr}
\hline \multirow{2}{*}{ Skenario } & \multicolumn{3}{c}{ DTA Cianteun } & \multicolumn{3}{c}{ DTA Cisadane Hulu } \\
\cline { 2 - 7 } & $\begin{array}{c}\text { Volume air } \\
\text { tahunan }\end{array}$ & $\begin{array}{c}\text { Pasokan air } \\
\text { bulan kemarau }\end{array}$ & $\begin{array}{c}\text { Neraca air } \\
\text { bulan } \\
\text { kemarau }\end{array}$ & $\begin{array}{c}\text { Volume air } \\
\text { tahunan }\end{array}$ & $\begin{array}{c}\text { Pasokan air } \\
\text { bulan kemarau }\end{array}$ & $\begin{array}{c}\text { Neraca air bulan } \\
\text { kemarau }\end{array}$ \\
\hline 1 & 337.711 .627 & 90.347 .944 & 44.677 .531 & 394.309 .521 & 88.494 .508 & -40.919 .729 \\
2 & 334.909 .351 & 97.905 .316 & 52.234 .904 & 386.319 .912 & 102.354 .127 & -27.060 .110 \\
3 & 336.121 .547 & 90.611 .108 & 44.940 .695 & 393.421 .431 & 89.159 .904 & -40.254 .333 \\
4 & 335.951 .228 & 92.421 .420 & 46.751 .007 & 392.977 .485 & 94.584 .644 & -34.829 .593 \\
5 & 333.080 .596 & 98.717 .996 & 53.047 .584 & 383.508 .079 & 102.999 .051 & -26.415 .186 \\
6 & 331.654 .850 & 106.138 .168 & 60.467 .756 & 382.524 .126 & 111.197 .598 & -18.216 .639 \\
\hline
\end{tabular}

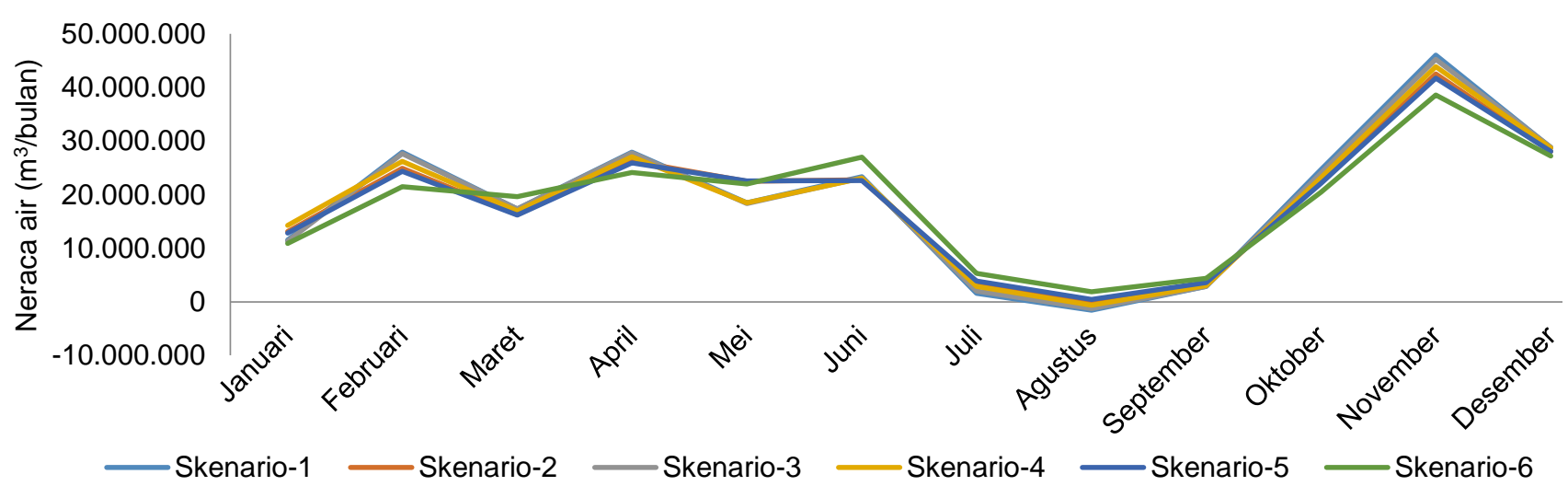

Gambar 6 Distribusi neraca air Daerah Tangkapan Air (DTA) Cianteun dari berbagai penerapan skenario. 
382.524.126 $\mathrm{m}^{3} /$ tahun. Pada bulan kemarau (MeiSepetember) DTA Cisadane Hulu mengalami defisit ketersediaan air. Nilai defisit tertinggi terdapat pada skenario 1, yaitu sebesar $-40.919 .729 \mathrm{~m}^{3}$, sedangkan defisit air terendah diperoleh dengan penerapan skenario 6 , yaitu sebesar $-18.216 .639 \mathrm{~m}^{3}$ yang dapat dilihat pada Gambar 7.

Hasil simulasi dari perencanaan penggunaan lahan dari berbagai sekenario pada DTA Cianteun dan Cisadane Hulu menunjukkan bahwa model penggunaan lahan yang terbaik untuk konservasi sumber daya air adalah dengan menerapkan berbagai kebijakan yang ada secara optimal dan peningkatan lahan pertanian agroforestry dengan mekombinasikan tanaman kehutanan. Dengan penerapan model penggunaan lahan tersebut maka degradasi lahan dapat dihindari, laju infiltrasi meningkat, mengurangi total limpasan, melindungi infrastruktur pada bagian hilir dan sebagai upaya pelestarian sumber daya air, sehingga dapat memberikan sumbangan besar pada ketersediaan air guna memenuhi kebutuhan air. Hasil skenario 6 dengan penerapan penggunaan lahan yang optimal dari berbagai stakeholder dan peningkatan lahan pertanian agroforestry mampu menurunkan defisit yang signifikan pada bulan kemarau di DTA Cisadane Hulu sebesar -18.216.639 $\mathrm{m}^{3}$ serta meningkatkan ketersediaan air pada DTA Cianteun sehingga memperoleh nilai surplus sebesar 60.467.756 $\mathrm{m}^{3}$. Perbandingan neraca air (water balance) hasil metode Mock dengan berbagai skenario di DTA Cianteun pada tahun 2018 dapat dilihat pada Tabel 3.

\section{KESIMPULAN}

Kebutuhan air DTA Cianteun dan Cisadane Hulu pada tahun 2018 masing-masing adalah sebanyak 108.952.291 $\mathrm{m}^{3} /$ tahun dan 308.733.311 $\mathrm{m}^{3} /$ tahun. Potensi ketersediaan air berdasarkan debit andalan dengan periode 10 tahun (2009-2018) pada DTA Cianteun diperoleh sebesar 248.584.986 m³/tahun dan pada DTA Cisadane Hulu sebesar 301.882.316 $\mathrm{m}^{3}$ /tahun. Neraca air DTA Cianteun surplus sebesar 139.632.695 m3/tahun, DAS Cisadane Hulu defisit sebesar $-6.850 .995 \mathrm{~m}^{3} /$ tahun. Penerapan penggunaan lahan terbaik berbasis sumber daya air di DTA Cianteun dan Cisadane Hulu adalah dengan penerapan skenario 2, di mana skenario ini relatif applicable dan mampu memperoleh hasil neraca air surplus sebesar 225.957.060 m³/tahun dengan neraca air bulan kemarau surplus sebesar $52.234 .904 \mathrm{~m}^{3}$. Model penggunaan lahan terbaik berbasis sumber daya air di DTA Cisadane Hulu adalah dengan penerapan skenario 6 yang merupakan penggunaan lahan yang optimal dari berbagai stakeholder mampu menurunkan nilai defisit yang signifikan pada bulan kemarau di DTA Cisadane Hulu sebesar -18.216.639 $\mathrm{m}^{3}$ dengan neraca air total surplus sebesar 73.790 .815 $\mathrm{m}^{3} /$ tahun.

\section{DAFTAR PUSTAKA}

Ahsoni MA. 2008. Perencanaan Penggunaan Lahan Berkelanjutan di Sub DAS Cisadane Hulu. Bogor (ID): Institut Pertanian Bogor.

[BPS] Badan Pusat Statistik. 2018. Kota Bogor Dalam Angka Tahun 2018. Bogor (ID): BPS Kota Bogor.

[BPS] Badan Pusat Statistik. 2018. Kabupaten Bogor Dalam Angka Tahun 2018. Bogor (ID): BPS Kota Bogor.

Departemen Pekerjaan Umum, Direktorat Jenderal Pengairan, 1985. Pedoman Perkiraan Tersedianya Air. Keputusan Direktur Jenderal Pengairan No. 71/KPTS/A/1985 Tanggal 5 Maret 1985. Jakarta (ID).

Fakhrurrazi F. 2012. Analisis Ketersediaan Air DAS Asam-asam Dengan Menggunakan Debit Hasil Perhitungan Metode Mock. Jurnal Poros Teknik. 4(2): 57-64.

Fitriati U, Novitasari N, Rusdiansya A, Rahman, A. 2015. Studi Imbangan Air Pada Daerah Irigasi

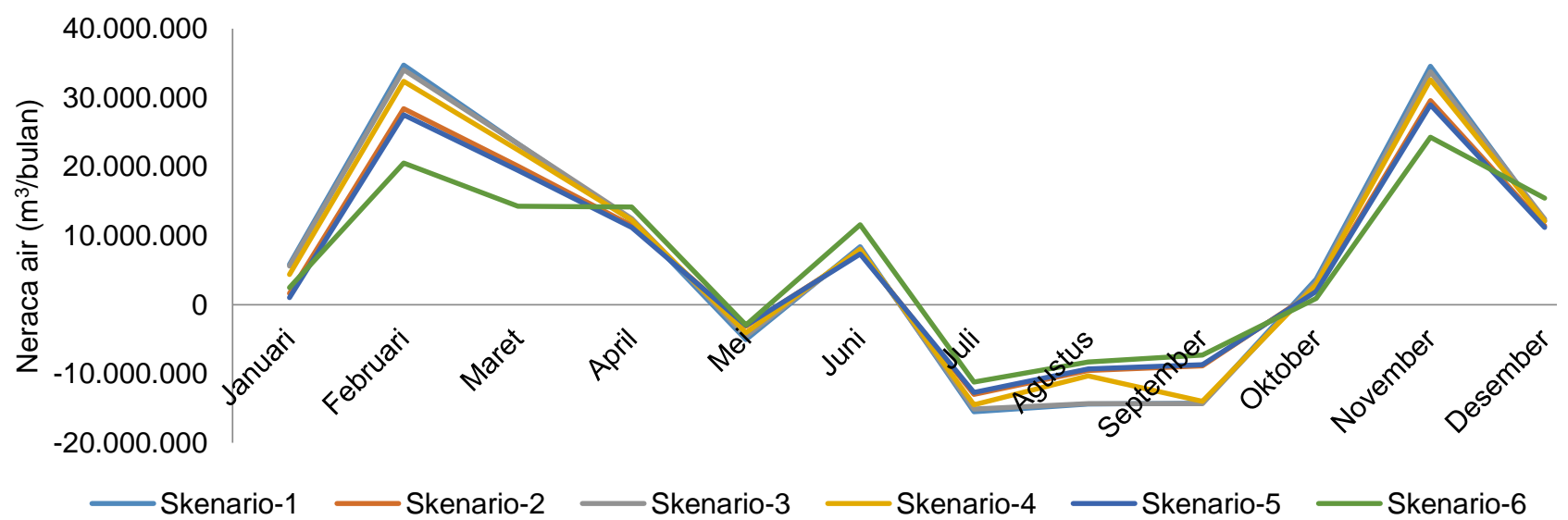

Gambar 7 Distribusi neraca air Daerah Tangkapan Air (DTA) Cisadane Hulu dari berbagai penerapan skenario. 
Pitap. Cantilever: Jurnal Penelitian dan Kajian Bidang Teknik Sipil. 4(1). https://doi.org/ 10.35139/cantilever.v4i1.9

Indarto. 2010. Hidrologi Dasar Teori dan Contoh Aplikasi Model Hidrologi. Jakarta : Bumi Aksara

Kodoatie RJ, Sjarief R. 2010. Tata Ruang Air. Yogyakarta (ID): Andi Offset.

Mock FJ. 1973. Land Capability Appraisal Indonesia. Bogor(ID): Water Avaibility Apprasial Report Prepared for the Land Capability Apprasial Project.

Motovilov YG, Gottschalk L, Engeland K, Rodhe A. 1999. Validation of a Distributed Hydrological Model Against Spatial Observations. Elsevier Agricultural and Forest Meteorology. 98: 257-277. https:// www.sciencebase.gov/catalog/item/50540573e4b0 $97 c d 4 f c f b 133$

Muis AB. 2017. Model Perencanaan Penggunaan Lahan Untuk Konservasi Sumber daya Air Di DAS Krueng Aceh. [Tesis] Bogor (ID): Institut Pertanian Bogor.

Noerhayati E.2015. Model Neraca Air Daerah Aliran Sungai dengan MINITAB. Malang (ID): Universitas Islam Malang

Nugroho R, Adi, Setiawan O. 2009. Analisi kekritisan hidrologi daerah aliran sungai untuk perencanaan pengelolaan DAS. Makalah Hasil Litbang Teknologi Pengelolaan DAS dalam Upaya Pengendalian
Banjir dan Erosi sedimen. Solo (ID): Balai Penelitian Kehutanan.

Popi R. 2011. Pengembangan Model Alokasi Air untuk Mendukung Optimal Water Sharing: Kasus DAS CicatihCimandiri, Kabupaten Sukabumi, Jawa Barat [disertasi]. Bogor (ID): Institut Pertanian Bogor

Serageldin I, Steer A. 1994. Making development sustainable: from concepts to action. The World Bank. https://elibrary.worldbank.org/doi/abs/ 10.1596/0-8213-3042-X https://elibrary.worldbank.org/doi/abs/10.1596/0

Sari IK., Limantara LM, Priyantoro D. 2012. Analisa ketersediaan dan kebutuhan air pada DAS Sampean. Jurnal Teknik Pengairan. 2(1): 29-41.

[SNI] Standar Nasional Indonesia. 2002. Penyusunan neraca sumber daya Bagian 1: Sumber daya air spasial. Badan Standardisasi Nasional. Jakarta (ID): SNI 19-6728.1-2002.

[SNI] Standar Nasional Indonesia. 20015. Penyusunan neraca sumber daya Bagian 1: Sumber daya air spasial. Badan Standardisasi Nasional. Jakarta (ID): SNI 6728.1-2015.

Tunas IG. Optimasi Parameter Model Mock Untuk Menghitung Debit Andalan Sungai MIU. Jurnal SMARTek. 5(1): 40-48. 